OPEN ACCESS

Edited by:

Christiane Hilger,

Luxembourg Institute of Health,

Luxembourg

Reviewed by:

Ulrich Matthias Zissler,

Technical University of Munich,

Germany

Dennis Russkamp,

Medigene Immunotherapies $\mathrm{GmbH}$,

Germany

*Correspondence:

Matthew D. Heath

matthew.heath@

allergytherapeutics.com

Specialty section:

This article was submitted to

Immunological Tolerance

and Regulation,

a section of the journal

Frontiers in Immunology

Received: 14 August 2020

Accepted: 19 October 2020

Published: 24 November 2020

Citation:

Heath MD, Mohsen MO, de Kam P-J,

Carreno Velazquez TL, Hewings SJ,

Kramer MF, Kündig TM,

Bachmann MF and Skinner MA (2020)

Shaping Modern Vaccines: Adjuvant

Systems Using MicroCrystalline

Tyrosine $\left(\mathrm{MCT}^{\circledR}\right)$.

Front. Immunol. 11:594911.

doi: 10.3389/fimmu.2020.594911

\section{Shaping Modern Vaccines: Adjuvant Systems Using MicroCrystalline Tyrosine $\left(\mathrm{MCT}^{\circledR}\right)$}

\author{
Matthew D. Heath ${ }^{1,2 *}$, Mona O. Mohsen ${ }^{3,4}$, Pieter-Jan de Kam ${ }^{1}$, \\ Thalia L. Carreno Velazquez ${ }^{1}$, Simon J. Hewings ${ }^{1,2}$, Matthias F. Kramer ${ }^{2,5}$, \\ Thomas M. Kündig ${ }^{6}$, Martin F. Bachmann ${ }^{4,7}$ and Murray A. Skinner ${ }^{1,2}$ \\ ${ }^{1}$ Allergy Therapeutics (UK) Ltd, Worthing, United Kingdom, ${ }^{2}$ Bencard Adjuvant Systems [a Division of Allergy Therapeutics \\ (UK) Ltd], Worthing, United Kingdom, ${ }^{3}$ Interim Translational Research Institute "iTRl", National Center for Cancer Care and \\ Research (NCCCR), Doha, Qatar, ${ }^{4}$ Department of BioMedical Research, Immunology RIA, University of Bern, Bern, \\ Switzerland, ${ }^{5}$ Bencard Allergie (GmbH), München, Germany, ${ }^{6}$ Dermatology, University Hospital Zurich, Zurich, Switzerland, \\ 7 Jenner Institute, Nuffield Department of Medicine, University of Oxford, Oxford, United Kingdom
}

The concept of adjuvants or adjuvant systems, used in vaccines, exploit evolutionary relationships associated with how the immune system may initially respond to a foreign antigen or pathogen, thus mimicking natural exposure. This is particularly relevant during the non-specific innate stage of the immune response; as such, the quality of this response may dictate specific adaptive responses and conferred memory/protection to that specific antigen or pathogen. Therefore, adjuvants may optimise this response in the most appropriate way for a specific disease. The most commonly used traditional adjuvants are aluminium salts; however, a biodegradable adjuvant, $\mathrm{MCT}^{\circledR}$, was developed for application in the niche area of allergy immunotherapy (AIT), also in combination with a TLR-4 adjuvant-Monophosphoryl Lipid A (MPL ${ }^{\circledR}$ )-producing the first adjuvant system approach for AIT in the clinic. In the last decade, the use and effectiveness of $\mathrm{MCT}^{\circledR}$ across a variety of disease models in the preclinical setting highlight it as a promising platform for adjuvant systems, to help overcome the challenges of modern vaccines. A consequence of bringing together, for the first time, a unified view of $M C T^{\circledR}$ mode-of-action from multiple experiments and adjuvant systems will help facilitate future rational design of vaccines while shaping their success.

Keywords: adjuvants, virus-like particles, MicroCrystalline Tyrosine (MCT ${ }^{\circledR}$ ), allergy, disease, immunization, Monophosphoryl Lipid A (MPL ${ }^{\circledR}$ ), vaccines

\section{INTRODUCTION}

\section{The Evolution of Vaccines and Adjuvants}

The concept of variolation (human inoculation/insertion of pathogens) dates back to the $10^{\text {th }}$ century in China, here, immunization against small pox used the live virus itself. Edward Jenner practised variolation in the UK and moved the field to the next level in the last decade of the $18^{\text {th }}$ century by using a cowpox virus for immunization which eventually led to the first vaccine (derived 
from vaccinia virus from vacca, the Latin word for cow), and the eradication of small pox in the $20^{\text {th }}$ century (1-3). Again, during the early 1900's the pioneering work of Louis Pasteur, Alexandre Yersin, and others was associated with the development of attenuated and inactivated vaccines which progressed for a variety of pathogens such as cholera, tetanus, polio, tuberculosis, and a severe pneumonia-form of plague (Yersinia pestis) (4-10).

"Discoveries [made] by accidents and sagacity, of things [the observers] were not in quest of" (1754, quoted in Merton and Barber 2004, p. 2) (11).

In the 1920's, both Alexander Glenny and Gaston Ramon were working with diphtheria toxins $(12,13)$. Production of bacterial toxins became very efficient (14). It was not long before Glenny referred to the use of a toxoid in humans for the first time in 1923 (13). Serendipity has led to some of the greatest discoveries and breakthroughs in science and medicine over the past century. Indeed, the story of adjuvants begins with a French veterinarian who unlocked a secret weapon, at an intersection of chance and wisdom. Gaston Ramon's (1886-1963) crucial discovery, whilst at the Pasteur Institute in Paris in the 1920's, made the observation that "local infection" (or abscesses at the injection site) was in some way enhancing antibody (Ab) production (15). As such, a series of experiments were set out and by adding a variety of substances (e.g., agar and starch oil) to an inoculation-substances he referred to as adjuvants (from the Latin adiuvare, meaning to help or aid) resulted in enhanced tetanus and diphtheria anti-serum production $(15,16)$. When Gaston Ramon discovered the immune potentiating effect of such adjuvants, the human population was reeling from the aftermath of the Spanish flu and faced burgeoning health risks from pathogens. Moreover, vaccination against viruses, for example, represented more of a challenge than vaccination against bacteria, mostly because it was more difficult to grow them.

As part of Glenny's work dealing with bacterial toxins, metal salts (precipitates thereof) were employed during the purification process, the adsorbed toxoid was subject to the wisdom of Glenny to perform comparative immunological studies, which indicated greatly enhanced immunological effects $(14,17)$, illuminating the serendipitous points of discovery that have shaped the modern world. Today, optimized versions of "alum" salt precipitates [e.g., aluminium oxyhydroxide; $\mathrm{AlO}$ $(\mathrm{OH})$, aluminium phosphate; AlPO4)] have been the mainstay of adjuvants in clinical vaccines for more than 70 years (16).

For most of this time, the scientific community considered the principle or "dogma" of explaining the effectiveness of aluminium adjuvants in the context of the "depot" effect immune stimulation through prolonged exposure of the antigen $(18,19)$. However, more research devoted to this question has revealed evidence that better explains adjuvancy in the context of alums physicochemical attributes and biological properties than a depot effect alone (20-26).

Tools to study the genome or cellular systems have developed rapidly. This has inspired new strategies from empirical to rational approaches to vaccine design and antigen carrier (nano)-systems, for targeting both innate and adaptive immune responses in tackling more challenging or emerging diseases or improvements in safety and efficacy of others (2729). Vaccines are disruptive technologies and one of the most cost-saving medical applications ever developed, and in the last decades, their application in non-infectious diseases such as allergy, cancer, diabetes, and even smoking cessation continue to be developed (30-34).

While recombinant vaccines have generally improved safety profiles compared with live-attenuated and whole-pathogen vaccines, they are also often less immunogenic due to the removal of their inherent pathogenic features and patterns. Modern vaccine development focusses on bridging or substituting this gap in order to improve their effectiveness without compromising safety. As a consequence, the development of new and sophisticated rational technologies such as antigen (nano)-carrier systems [e.g., virus-like particles (VLPs)] or combination of adjuvants (adjuvant systems) are being employed to help overcome these challenges $(29,35)$.

\section{Adjuvant Systems}

Adjuvant Systems may comprise of a variety of classical adjuvants or immunomodulators that are combined and tailored for the specific antigen and target application. The immune system has evolved to recognise repetitive surface features like pathogen-associated molecular patterns (PAMPs), which forms the basic principles in how they are able to activate the innate immune system, which, in turn, leads to orchestration of a specific adaptive response.

The benefits of vaccines and immunization against pathogenic threats demonstrate a convincing positive benefitrisk ratio over many decades, with the scope to eradicate disease. The existing and evolving threats have been brought to light recently with the spread of SARS-Cov-2, which some have described as natures wake-up call to complacent civilisation; threatening our era of peak globalisation, which has grown under a safety net of medical and scientific advances. The consideration of adjuvants in new vaccine development can be the difference to what makes a vaccine effective or not. Particularly, so where pathogens with more complex life cycles with intracellular habits or pathogens with genetic variability exist. Optimizing vaccines for this purpose has been historically slow and cumbersome (e.g., influenza, HIV, and malaria) and often requires a more robust adaptive response. For billions of years, microbes have evolved in this way, and this complexity has only just begun to be better understood by scientists.

\section{Immunology, Immunization, and Immunotherapy}

The innate and adaptive responses cover two broad phases of the body's response to a pathogen or vaccine. Pattern recognition receptors (PRRs) on innate and adaptive immune cells [i.e., macrophages, dendritic cells (DCs), monocytes, neutrophils, and $B$ cells] have evolved to recognise conserved features that are typical of pathogenic surface patterns [pathogen-associated molecular patterns (PAMPs)], thus being able to signal an incoming agent as a threat, that is distinguishable from "self" $(16,36,37)$. PRRs will trigger intracellular signaling cascades, 
resulting in the production of pro-inflammatory cytokines. This early inflammatory response to infection or immunization is diverse and tightly regulated, its early orchestration shaping the quality in adaptive immunity. A key mediator in shaping the quality of this adaptive response are antigen-presenting cells (such as DCs, macrophages, and B cells), particularly where vaccines are concerned (16).

How effectively a pathogen is removed will depend on the interplay between the innate and adaptive response and the quality that sits behind this immune reaction. In essence, the immune response to infection involves innate immune activation and antigen-specific responses of $\mathrm{B}$ and $\mathrm{T}$ cells, with the ideal vaccine typically able to induce Th1/Th17 immune responses that can direct this toward inactivation and removal of the threat, followed by development of immune memory (Figure 1) (16).

Allergy or parasitic infections are somewhat distinct, inducing strong type-2 immune responses. While Th2/IgE responses control parasitic infections, robust response to parasitic infections is also associated with allergic phenomena (38). Type 1 allergy is mediated by specific IgE, which results in an exaggerated immune response against an otherwise harmless substance. However, growing evidence of a negative association between parasitic infections and allergy at an ecological level highlights the complex inter-relationship between the two (39). Allergic disease is considered a new epidemic of the $21^{\text {st }}$ century, a burgeoning disease particularly in urban areas (40). The most effective way to treat IgE-mediated allergies is through allergenspecific immunotherapy (AIT), which entails repeated administration of specific allergens to patients resulting in protection against the allergic and inflammatory reactions (41). Despite its success, subcutaneous immunotherapy is generally slow and cumbersome for the patient. However, the advances in vaccinology may be exploited here too with the advent of new antigen nano-carriers, modified ways in presenting the allergen and next-generation adjuvants that may advance treatment for chronic diseases and emerging/re-emerging diseases into the modern world (42).

\section{Tailoring Adjuvant Systems}

The combination of adjuvants (adjuvant systems) have been pioneered for the last few decades and has resulted in significant advancements in vaccine design and treatments. However, only few alternative adjuvants (other than alum) have been approved for human use (Table 1).

Antigen carrier systems such as VLPs can be engineered to optimise antigen presentation and harbour intrinsic adjuvanticity, as these can be packaged with immunomodulators/adjuvants or combined with depot adjuvants to further tailor and optimise the immune response appropriately $(29,30,50)$. The most commonly used traditional adjuvants are aluminium salts; however, for decades, a biodegradable adjuvant based on the crystalline form of the non-essential amino acid L-Tyrosine, $\mathrm{MCT}^{\circledR}$, has been utilized in the niche area of allergy immunotherapy $(43,45)$. It is only in the last decade that its use and effectiveness across a variety of challenging disease models in the preclinical setting highlights it as a promising platform for adjuvant systems to help overcome the challenges associated with modern vaccines and challenging diseases (29).

The application of $\mathrm{MCT}^{\circledR}$ as an adjuvant has more recently been extended across a broader vaccine scope with and without VLP antigen carrier systems; one such VLP system uses the cucumber mosaic VLP ( $\left.\mathrm{CuMV}_{\mathrm{TT}}\right)$, which includes intrinsic adjuvant features such as an engineered universal $\mathrm{T}$ helper cell epitope $\left(\mathrm{CD} 4^{+}\right.$, based on the tetanus toxin) and encapsulated RNA (TLR7/8 agonists) (51). The disease challenge models which have screened $\mathrm{MCT}^{\circledR}$-adjuvanted vaccines consist of

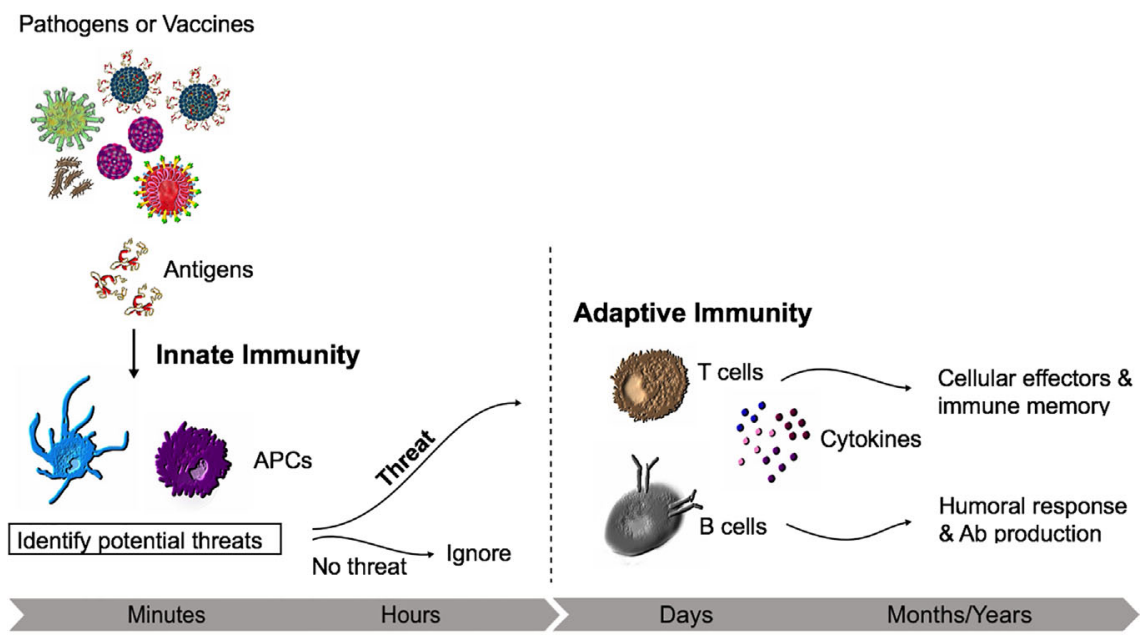

FIGURE 1 | Innate and adaptive immunity time course. The non-specific early inflammatory response is characterized by cells of the innate immune system (e.g., Macrophages) which will recognise conserved repetitive features from bacteria or viruses. If recognized as a threat, the adaptive immune responses develops with the activation of lymphocytes. 
TABLE 1 | Adjuvants used in licensed vaccines and immunotherapy [adapted from Di Pasquale et al. (16)].

\begin{tabular}{|c|c|c|c|}
\hline Adjuvant & Composition & Immunomodulation & Product Indications \\
\hline Aluminium (alum) & $\begin{array}{l}\text { Aluminium salts mixed with antigens } \\
\text { aluminium oxyhydroxide; } \mathrm{AlO}(\mathrm{OH}) \\
\text { aluminium phosphate; AlPO4 }\end{array}$ & $\begin{array}{l}\text { Th2-biased, prolonged immune exposure (DC uptake), } \\
\text { DAMP, Inflammasome activation, potent innate/Ab and } \\
\text { inflammatory responses }\end{array}$ & $\begin{array}{l}\text { Diphtheria, tetanus, pertussis, } \\
\text { poliomyelitis, hepatitis A, hepatitis B, } \\
\text { meningococcal, pneumococcal }\end{array}$ \\
\hline Virosomes & $\begin{array}{l}\text { Phospholipid membrane (either a mono- } \\
\text { or bi-layer) vesicle incorporating virus } \\
\text { derived proteins }\end{array}$ & Target antigen-presenting cells (APCs) and B cells & Hepatitis and influenza \\
\hline $\begin{array}{l}\text { AS03/ } \\
\text { Oil-in-water/ } \\
\text { MF59 }\end{array}$ & Squalene-based & Increase antigen uptake by APCs, Ab B cell responses, & Influenza pandemic and seasonal. \\
\hline ASO4 & $\begin{array}{ll}\text { - } & \text { Aluminium salt; } \mathrm{AlO}(\mathrm{OH}) \\
\text { - } & \text { 3-deacyl-monophosphoryl lipid } \mathrm{A}\end{array}$ & $\begin{array}{l}\text { Increase antigen uptake by APCs, TLR-4 agonist, Th1 - } \\
\text { biased Ab responses }\end{array}$ & Hepatitis B and Human Papillomavirus \\
\hline AS01 & $\begin{array}{l}\text { Liposome-based } \\
\text { - } \quad \text { 3-deacyl-monophosphoryl lipid A } \\
\text { - } \quad \text { Purified saponin; QS-21 }\end{array}$ & $\begin{array}{l}\text { Th1-immunity } \\
\text { Early innate inflammasome activation, } \\
\text { Antigen-specific CD4+ T cells in addition to antigen-specific } \\
\text { Abs, robust IFN- } \gamma \text { response. }\end{array}$ & $\begin{array}{l}\text { Recombinant zoster vaccine (Shingrix, } \\
\text { RZV). } \\
\text { Mosquirix (Plasmodium falciparum; RTS, } \\
\text { S'). }\end{array}$ \\
\hline Montanide ISA51 & Mineral oil & Increase antigen uptake by APCs, Ab B cell responses & Non-small cell lung cancer \\
\hline $\mathrm{MCT}^{\circledR}$ & $\begin{array}{l}\text { Crystalline form of L-Tyrosine } \\
\text { (MicroCrystalline Tyrosine); MCT }{ }^{\circledR}\end{array}$ & $\begin{array}{l}\text { Biodegradable depot }(43,44) \text {, Th1-biased, Increase antigen } \\
\text { uptake by APCs, highly immunogenic B and T cell responses } \\
\text { (45). }\end{array}$ & $\begin{array}{l}\text { Pollinex }{ }^{\circledR} \text { short-course allergy } \\
\text { immunotherapy. }\end{array}$ \\
\hline $\mathrm{MCT}^{\circledR}-\mathrm{MPL}^{\circledR}$ & $\begin{array}{l}\text { Crystalline form of L-Tyrosine } \\
\text { (MicroCrystalline Tyrosine); MCT }{ }^{\circledR} \\
\text { 3-deacyl-monophosphoryl lipid A }\end{array}$ & $\begin{array}{l}\text { Th1-biased, Increase antigen uptake by APCs, highly } \\
\text { immunogenic B and T cell responses. TLR-4 agonist, Th1 - } \\
\text { biased Ab responses }(46,47)\end{array}$ & $\begin{array}{l}\text { Pollinex Quattro }{ }^{\circledR} \text { short-course allergy } \\
\text { immunotherapy }(48,49) \text {. }\end{array}$ \\
\hline
\end{tabular}

largely murine data (malaria and cancer melanoma models), and one Ferret model (H1N1 Influenza) (50, 52-54). It is important to note that the proof of concept disease models capture biomarker measurements indicative of protection (efficacy) compared to control groups, with performance of the vaccine assessed against groups formulated with alum. Extended pharmacokinetic experiments featured in the Melanoma model (VLP-MCT ${ }^{\circledR}$ )provides unique insights into the importance of the depot effect of $\mathrm{MCT}^{\circledR}$ when combined with nanoparticles in orchestrating a robust adaptive cytotoxic T cell response (50).

\section{MCT $^{\circledR}$ AND MONOPHOSPHORYL LIPID-A IN ALLERGY IMMUNOTHERAPY}

$\mathrm{MCT}^{\circledR}$ is a biodegradable depot adjuvant developed primarily for use in short-course subcutaneous allergy immunotherapy (AIT), in combination with native allergens or modified allergens (allergoids) with or without Monophosphoryl Lipid $A^{\circledR}$ (MPL ${ }^{\circledR}$, a Toll-like receptor 4 agonist) (48). Allergoid $\mathrm{MCT}^{\circledR}{ }_{-}$ MPL ${ }^{\circledR}$ formulations are referred to as Pollinex Quattro ${ }^{\circledR}$. Clinical evidence for the use of allergoid-MCT ${ }^{\circledR}-\mathrm{MPL}^{\circledR}$ adjuvant systems in allergy immunotherapy is well documented $(55,56)$. Combining an allergoid with an adjuvant system pays tribute to the short-course posology of the vaccine, which is administered in four to six injections within a year preseasonally, as opposed to longer-treatment courses ( $>30$ injections) that are commonly applied in AIT and which are typically combined with alum depots (57).

The most recent phase II studies (including the optimal dose levels planned for Phase III) have recently been published for a six-injection presentation of Pollinex Quattro (PQ) Birch and PQ Grass $(49,55)$. These products are subject to further clinical development, and a phase III trial for both PQ Birch and PQ Grass are currently planned. Furthermore, a combined transcriptomic and proteomic biomarker analysis is pending in a phase III study for PQ Grass, while a smaller preliminary data set is available from an earlier trial, establishing some initial hypotheses related to mode-of-action/predictive efficacy biomarkers (46). Furthermore, Pollinex Quattro is listed in the current European Academy of Allergy and Clinical Immunology (EAACI) AIT guidelines with grade IA recommendation (56).

The PQ products employing the $\mathrm{MCT}^{\circledR}$ and $\mathrm{MPL}^{\circledR}$ adjuvant system are designed to desensitise allergic individuals by modulating the inherent Th1/Th2 imbalance of atopic disease. The mechanism involved in $\mathrm{MCT}^{\circledR}-\mathrm{MPL}^{\circledR}$ adjuvancy has not been fully elucidated, but the synergistic attenuation of IgG may prolong protective immunity, which is a further benefited by combining the two adjuvants. The added benefit of MPL ${ }^{\circledR}$ has been demonstrated in the clinic too (58). Several possible mechanisms might account for Toll-like receptor 4 (TLR-4) mediated effects in atopy and asthma. For instance, signaling through the TLRs is generally associated with production of Th1 cytokines by DCs via IL-12, leading to increased IFN- $\gamma$ production (59).

For the PQ product portfolio, in total, 26 Phase I-III clinical trials have been conducted using various allergoids, with different formulations and dosing posologies, including 4695 patients in total (Table 2).

The combination of $\mathrm{MCT}^{\circledR}$ and $\mathrm{MPL}^{\circledR}$ has been shown to be safe and well tolerated in these Phase I-III studies and based on post-marketing data, i.e., >150,000 individuals have received PQ treatment (2004-2019) and an estimated $>450,000$ treatment courses have been dispensed (Data on file, Allergy Therapeutics plc). Moreover, the safety of MPL ${ }^{\circledR}$ has been demonstrated in several products using $\mathrm{MPL}^{\circledR}$ as an adjuvant (60). MPL ${ }^{\circledR}$ is currently used as an adjuvant in the licensed product Cervarix 
TABLE 2 | Overview of clinical studies performed with Pollinex Quattro (PQ) products (Data on file, Allergy Therapeutics Plc).

\begin{tabular}{lcccc}
\hline & Phase I & Phase II & Phase III & Total \\
\hline PQ Ragweed & 1 & 3 & 1 & 5 \\
PQ Grass & 4 & 8 & 1 & 13 \\
PQ Tree & 1 & 3 & 1 & 5 \\
PQ Birch & 0 & 2 & 1 & 3
\end{tabular}

(human papilloma virus vaccine), Fendrix (hepatitis B vaccine), and Shingrix [herpes zoster (shingles)] (60). Since first being licensed in 2006, over 200 million doses of HPV vaccines have been distributed globally, no significant safety issues have been observed (WHO, 2016).

In relation to $\mathrm{MCT}^{\circledR}, 1575$ patients have received $\mathrm{MCT}^{\circledR}$ alone as placebo group in placebo controlled GCP studies (including 9 million injections of all $\mathrm{MCT}^{\circledR}$ platforms) (Data on file, Allergy Therapeutics plc). $\mathrm{MCT}^{\circledR}$ as an adjuvant alone has been shown to be safe and well tolerated, without any treatment related serious adverse events (SAEs) being reported and no relevant effects observed in safety laboratory and vital signs. In a recent position paper, authored by an independent taskforce of EAACI members, a review of adjuvants and formulations currently used in marketed allergy immunotherapies discussed, stating, "Since its introduction into AIT in 1970, there are no specific safety concerns known for $M C T^{\circledR}$. It can be anticipated that this fully biodegradable adjuvant will also in future studies not reveal side effects" (61).

\section{MCT $^{\circledR}$ MODE OF ACTION}

In depth comparative adjuvant studies are, in general, limited in number, which may in part be due to the proprietary nature of investigational adjuvants. Since alum is the adjuvant of choice and most broadly studied, it is a useful comparator to use when studying vaccine mode-of-action.

MCT $^{\circledR}$ and alum have been compared head-to-head in a number of preclinical mouse models. In one such study, $\mathrm{MCT}^{\circledR}$ combined with Ovalbumin stimulated striking and comparable B cell responses (antigen-specific IgG1, IgG2a, IgG2b, and IgG3) (45). The relevant induction of IgE was of interest, since IgE antibodies (Abs) are the key mediator of the allergic response and an "unwanted" reaction. Here, $\mathrm{MCT}^{\circledR}$ triggered less $\operatorname{IgE}$ production than alum. This is an observation that has been consistently described in other studies, highlighting a key benefit in using a Th1-biased depot adjuvant in AIT and its reported synergy when combined with MPL ${ }^{\circledR}$ as an adjuvant system $(45$, 52-54). The specific $\mathrm{T}$ cell (CD4+) cytokine response may, in part, explain this since $\mathrm{MCT}^{\circledR}$ induced a more Th1-biased response. Of note, IL-4 is required for the Ig switch to IgE, and the lower propensity to induce IL-4, compared to alum, supports this notion (45). Both Alum and $\mathrm{MCT}^{\circledR}$ were found to activate the inflammasome but this activation was not essential for the stimulation of $\mathrm{B}$ and $\mathrm{T}$ cell responses, nor early inflammatory markers (i.e., eosinophils and neutrophils) which were induced by $\mathrm{MCT}^{\circledR}$ and alum adjuvants, when assessed by peritoneal lavage (45). Similar results have been reported for alum in mice deficient in IL-1R or NLRP3 $(26,62)$. Hence, although alum and $\mathrm{MCT}^{\circledR}$ may activate the inflammasome in vitro, this does not affect the adaptive immune response needed for $\mathrm{Ab}$ production in AIT. Furthermore, increased B and T cell responses induced with alum or $\mathrm{MCT}^{\circledR}$-based vaccines did not depend on signaling through toll-like receptors, which is distinct from the TLR agonist MPL ${ }^{\circledR}(45)$.

$\mathrm{MCT}^{\circledR}$ 's half-life at the injection site was modelled in preclinical models, with an estimated half-life of 48 hours (44). $\mathrm{MCT}^{\circledR}$ has a broad adsorption capacity with model allergens and carriers such as VLPs (63). The depot effect has been characterized with VLP nanoparticles, and this prolonged immune exposure was attributed to play an important role in priming $\mathrm{T}$ cells and, in particular, stimulating cytotoxic T cellsa response in which other adjuvants struggle to confer (50).

Shardlow and Exley have further characterized the physicochemical properties of $\mathrm{MCT}^{\circledR}$, which describes needle-like crystalline structures, some of which stack together, to produce a high degree of structural order (64). The resultant crystals combined to form extensive rod-like features the majority of which exceeded $10 \mu \mathrm{m}$ in length under physiological conditions (median size ca. 21 $\mu \mathrm{m}) . \mathrm{MCT}^{\circledR}$ also appeared to lack a water decomposition phase by Thermogravimetric analysis, which indicated the lack of physically adsorbed moisture at the surface interface. A decrease in hydroxyl display/surface functionality has been associated with the reduced reactivity of aluminium salts in vitro in terms of proinflammatory cytokine production, reactive oxygen species (ROS) generation and inflammasome activation. The size of $\mathrm{MCT}^{\circledR}$ may influence its recognition and uptake by THP-1 macrophages in vitro (64). In general, adjuvant particles between 1 and $3 \mu \mathrm{m}$ in size have been considered optimal for recognition and engulfment by macrophages (65). The large hydrodynamic length of $\mathrm{MCT}^{\circledR}$ crystals in biological medium $(>$ ca. $10 \mu \mathrm{m})$ appeared to partially stymie the scavenging capacity of THP-1 macrophages in vitro (64). This may contribute to the safety profile of $\mathrm{MCT}^{\circledR}$, since limited macrophage uptake may prohibit transport via barriers such as blood-brain and rapid transport to lymph nodes. The lower propensity to induce IgE/ Th2-polarized responses and early inflammatory responses compared to alum, as described in Leuthard et al., 2018, may be partly attributed to the size and distribution of larger and more ordered crystalline structures of L-Tyrosine (45). This is in stark contrast to results obtained using a crystalline aluminium adjuvant where its optimal particle size (median size, $1.4 \mu \mathrm{m}$ ) appeared to more readily facilitate cytoplasmic loading (64).

Both adjuvants were characterized by immediate infiltration of neutrophils and eosinophils (MCT ${ }^{\circledR}$ to a lesser degree) (45). This was the only study, to our knowledge, to characterize such inflammatory responses for $\mathrm{MCT}^{\circledR}$. Although many innate reactions are important for the onset of adaptive immunity, the role of inflammasome activation in immunization and AIT has not been precisely defined. Indeed, $\mathrm{MCT}^{\circledR}$ harbors different physicochemical properties, such as particle size, morphology, adsorption characteristics, and local pharmacokinetics compared to alum, which undoubtedly plays a pivotal role in shaping the quality of the Th1/Th2 biological response. $\mathrm{MCT}^{\circledR}$, s roles in the innate and adaptive response are outlined in Figure 2. 


\section{MCT ${ }^{\circledR}-\mathrm{MPL}^{\circledR}$ "Synergy"}

The physical association of MPL ${ }^{\circledR}$ for $\mathrm{MCT}^{\circledR}$ has been characterized using fluorescently labeled LPS (Lipopolysaccharide) as a substitute for $\mathrm{MPL}^{\circledR}$ (Figure 2). The LPS was labeled with fluorescein isothiocyanate (FITC). Through confocal microscopy, it was possible to see that the labelled LPS is associated with the $\mathrm{MCT}^{\circledR}$ depot. Furthermore, in Bell et al., 2015 allergoid and $\mathrm{MPL}^{\circledR}$ adsorption to $\mathrm{MCT}^{\circledR}$ in PQ allergy AIT formulations was determined in vitro using specific allergen $\operatorname{IgE}$ allergenicity and MPL ${ }^{\circledR}$ content methods (63). The predominant mode (i.e., force) of adsorption between $\mathrm{MPL}^{\circledR}$ and $\mathrm{MCT}^{\circledR}$ was investigated by competition inhibitor binding experiments. This was predominantly inferred as $\mathrm{C}-\mathrm{H} \cdots \pi$ interactions between the 2deoxy-2-aminoglucose backbone on $\mathrm{MPL}^{\circledR}$ and aromatic ring of L-tyrosine in MCT $^{\circledR}$ (63) (Figure 3B). Furthermore, the physical association of MPL ${ }^{\circledR}$ across the needle-like crystalline structure of 20 $\mathrm{mg} / \mathrm{ml} \mathrm{MCT}{ }^{\circledR}$ has been characterized using fluorescently labeled LPS as a substitute for MPL ${ }^{\circledR}$ via confocal microscopy (Figure 3A).

Immunological synergy has been documented in allergoid formulations with or without MPL ${ }^{\circledR}$, highlighting a synergistic relationship in IgG induction $(47,58)$. Formulation science is often an overlooked or under-appreciated discipline and often adjuvants may be included into formulations without having an extended level of characterisation of their interactions and compatibility with active substances and/or other adjuvants. Indeed, adsorption characteristics of adjuvants may shape bioavailability and in turn vaccine effectiveness (ratio of free versus adjuvants bound antigen may determine antigen draining kinetics) (28). MCT $^{\circledR}$ demonstrates consistent adsorption characteristics, when combined with antigens and allergoids (63). As such, quality attributes may be controlled for over the course of the products shelf life and investigated in preclinical

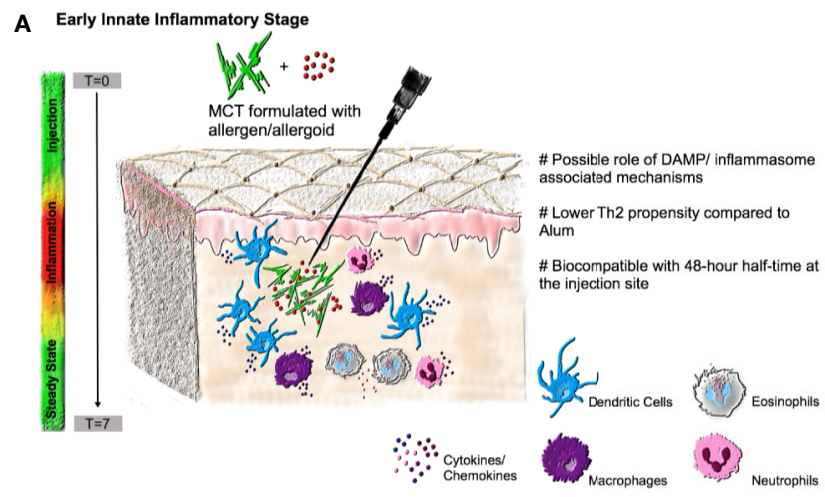

B

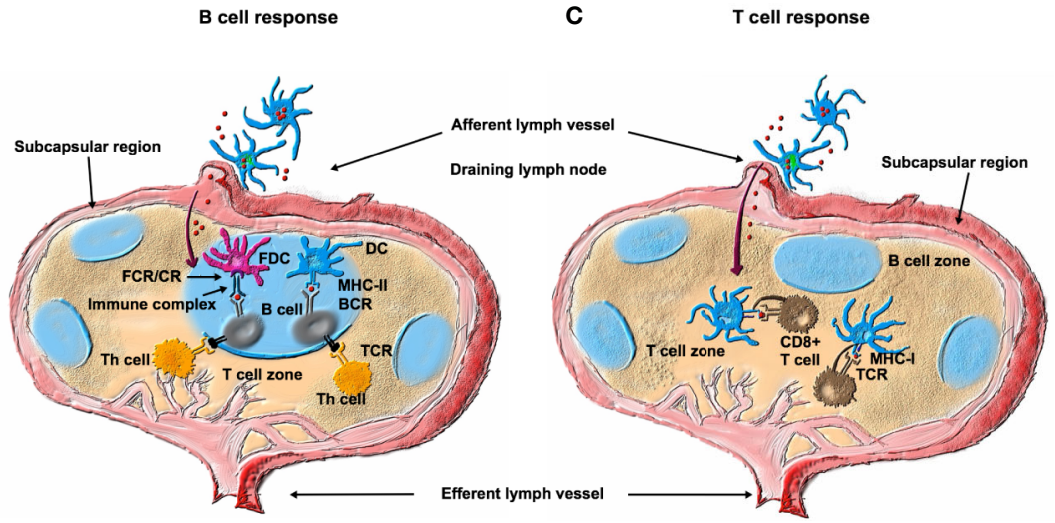

FIGURE 2 | An overview of the immune response after vaccination with an MCT ${ }^{\circledR}$ depot. (A) The early innate response is characterized by immediate exudation of neutrophils and eosinophils in vivo. The role of inflammasome/DAMP-associated mechanisms have not been precisely defined. The innate response has recorded an increase in dendritic cells (DCs), observed $24 \mathrm{~h}$ post-injection (45). MCT ${ }^{\circledR}$ is biodegradable/biocompatible with an estimated half-life of $48 \mathrm{~h}$ at the injection site (44). As a result, it is cleared within 7 days with a return to a local steady state. The biodegradable depot properties of $\mathrm{MCT}^{\circledR}$ are thought to be key in orchestrating the subsequent adaptive response. (B) The infiltrating antigen presenting cells to the draining lymph node, induce sustained and robust $\mathrm{B}$ cell response, via MHC class II antigen presentation (45, 52-44, 54), with sustained lgG antibody titers. The prolonged immune exposure of antigen is thought to further DC uptake and initiate CD4 T helper cell (Tfh) clonal expansion and differentiation (45). Furthermore, immune complexes may form with follicular dendritic cells (FDCs) via Fc $\gamma$ receptors (Cd16 and CD32) and complement receptors (CD35). (C) The depot properties of $\mathrm{MCT}^{\circledR}$ have been shown to be key in generating a more robust cytotoxic T cell response, thus the priming of $\mathrm{T}$ cells combined with optimal antigen delivery, such as when combined with VLPs, are key drivers in orchestrating this arm of the adaptive response (50). 
immunogenicity models of the disease to further tailor and optimise properties of vaccines.

\section{$\mathrm{MCT}^{\circledR}$ Combined With Poorly Immunogenic Antigens}

It is important to note that the combination of $\mathrm{MCT}^{\circledR}$ with poorly immunogenic antigens such as Ovalbumin (45), CSP (53), and $\mathrm{H} 1 \mathrm{~N} 1$ (54) produce consistent results in generating a robust $\mathrm{B}$ cell response and protective efficacy in preclinical models. $\mathrm{MCT}^{\circledR}$ was found to possess high protein-binding capacity (adsorption compatibility with the antigens) (54, 63). In the influenza study, a close correlation of haemagglutination inhibition and neutralization titres in groups formulated with $\mathrm{MCT}^{\circledR}$ or alum suggests that the two adjuvants were inducing functionally equivalent influenza-specific Abs. Leuthard et al., 2018 using Ovalbumin, highlighted similar findings (45). However, key differences related to $\mathrm{MCT}^{\circledR}$, s physicochemical properties (particulate structure), depot function and biased Th1 specificity highlights some key distinctions of the platform that should be considered when assessing other adjuvants to combined, tailor and optimise the immune response appropriately for specific disease applications.

\section{MCT $^{\circledR}$ IN VIRUS-LIKE PARTICLE FORMULATIONS: HELPING OVERCOME THE CHALLENGES OF MODERN VACCINES}

VLPs can be engineered a specific way to modulate the immune response. In pathogen-specific prophylactic applications, they have proven to be well tolerated and highly immunogenic. The $21^{\text {st }}$ century sees further advancements of the technology harnessing state-of-the-art techniques in leveraging the platform to tackle complex diseases. Mohsen et al., 2020 pay tribute to these advancements in the context of the design, delivery and draining dynamics of VLPs (29) and their respective stages of clinical development and success (30). Table 3 summarizes immunological mechanisms of VLP-based

\section{A}

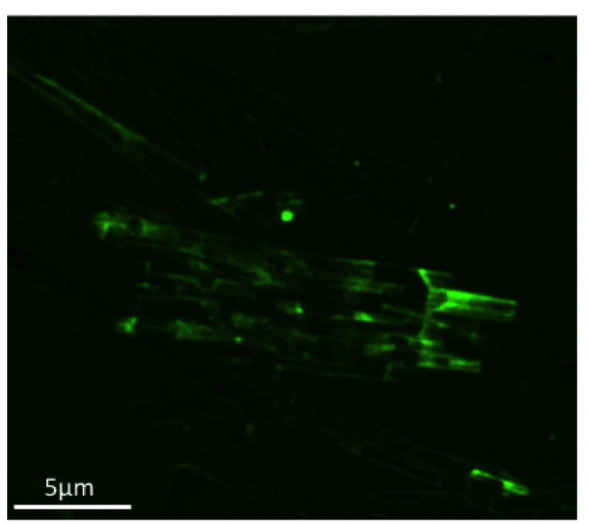

B

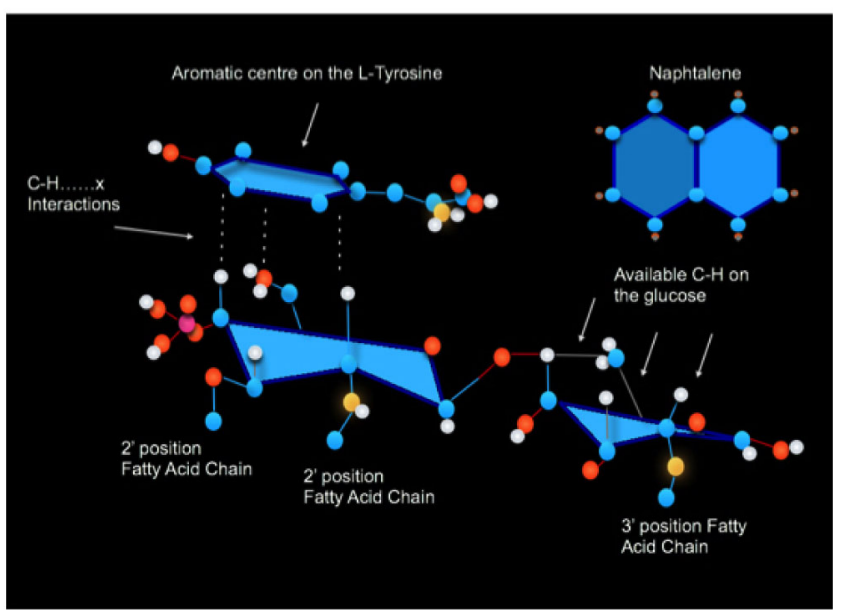

FIGURE 3 | (A) The physical association of $\mathrm{MPL}{ }^{\circledR}$ across the needle-like crystalline structure of $20 \mathrm{mg} / \mathrm{ml} \mathrm{MCT^{ \circledR }}$ has been characterized using fluorescently labeled LPS (100 $\mu$ g; Lipopolysaccharide) as a substitute for MPL ${ }^{\circledR}$ via confocal microscopy. (B) Proposed C-H $\cdots \pi$ interactions between the 2-deoxy-2-aminoglucose on MPL ${ }^{\circledR}$ and the aromatic ring on L-tyrosine, based on inhibitor studies with Naphthalene (Adapted from Bell et al., 2015). 
vaccines in the context of tailoring VLP-platforms with $\mathrm{MCT}^{\circledR}$ as an adjuvant system.

In regards to targeting $B$ cells and Abs, a major factor here relates to the size and ability of VLPs to display antigens in optimal fashion [repetitive antigen display, Pathogen Associated Structural Patterns (PASPs)], resulting in very robust induction in $\mathrm{Ab}$ responses. In an elegant study by Link and colleagues, 2012 the importance of size and repetitive structure as critical factors for efficient Ag presentation to B cells was demonstrated. In this case, IgM Abs which VLPs are recognized by, recruit the complement component $\mathrm{C} 1 \mathrm{q}$ followed by activation of $\mathrm{C} 3$, resulting in persistent deposition of antigen on follicular dendritic cells (FDCs) via complement receptor CD35 $(29,69)$. Furthermore, the physical association of a repetitive antigen display distanced by $5-10 \mathrm{~nm}$ permit optimal B cell receptor crosslinking. The size of VLPs $(20-200 \mathrm{~nm})$ enable efficient fast and transient trafficking of native antigen to the lymph nodes highlighting pharmacokinetic advantages of the platform and their ability to target APCs to orchestrate a robust adaptive response (66).

Vaccines targeting pathogens that are more complex will need to induce both $\mathrm{B}$ and effector T cells, which is where adjuvant design may come into play more deeply. If our understanding related to the mode-of-action of depot adjuvants/immunomodulators, continue to grow and become more well established, effective rational approaches in VLP vaccine design may be taken in tailoring dynamic responses of desired specificity.

Adjuvants physically associated with VLPs (e.g., TLR ligands) may enhance B cell responses. Prokaryotic RNA is known to be more effective and superior in this regard and, most importantly, is the ability of this adjuvant-effect to help differentiate a memory B cell pool into secondary plasma cells, which produce very high levels of Abs. This may allow for more efficient and rapid control of an evolving pathogen $(67,70,71)$. The CuMV TT $_{\text {VLP }}$ is an example of this, based on an ssRNA plant virus, engineered to harbour a universal $\mathrm{T}$ cell epitope derived from the tetanus toxoid, to optimise $\mathrm{T}$ cell help for B cells (51). The CuMV encapsulates pRNA, which acts as a TLR 7/8 ligand. This particular platform has been remarkably effective in generating proof of concept data in different veterinary vaccines for insectbite hypersensitivity in horses (IL-5), atopic dermatitis in dogs (IL-31), and preclinical PoC in allergy (peanut and cat), pain in osteoarthritis (NGF), Zika virus infection (ED-III), psoriasis (IL17a), and malaria (PvTRAP and PvCSP) (51-53, 72-78).

\section{CuMV $_{\mathrm{TT}}$ in a Peanut Allergy Model}

Where allergic disease is concerned, VLPs have achieved preclinical proof of concept and are subject to further clinical development, notably for peanut allergy $(32,74)$. Here, targeting $\mathrm{B}$ cells using $\mathrm{CuMV}_{\mathrm{TT}}$ combined with a single major allergen, was able to protect against a complex peanut extract in a murine anaphylaxis model (74). In this study mice were immunized with one of three vaccines containing either a mixture of allergens found in whole extract of roasted peanut or with just one single, purified peanut allergen ("Ara h 1" or "Ara h 2"). Regardless of which vaccine was used, immunization strongly reduced systemic and local allergic symptoms in vaccinated subjects and protected against anaphylaxis upon subsequent challenge with a whole peanut allergen mixture. The fact that one injection against a single allergen was sufficient to induce protection against a whole peanut allergen mixture has never been described before and could be applied in different relevant allergies. In addition, the vaccine proved hypoallergenic as previously described (79), which in peanut allergy is a vital characteristic to avoid anaphylactic reactions upon dosing and to improve patient uptake.

\section{CuMV $_{\mathrm{TT}}-\mathrm{MCT}^{\circledR}$ in a Malaria Disease Model}

The inclusion of the depot adjuvant $\mathrm{MCT}^{\circledR}$ has highlighted the effectiveness of prolonged physical release of VLP nanoparticles, which have been shown to be particularly effective at priming effector $\mathrm{T}$ cell responses. In a number of different comparative adjuvant studies in disease challenge models for Malaria ( $P$. vivax) and Cancer (Melanoma), a step-wise improvement in biomarkers/ disease progression, with the addition of $\mathrm{MCT}^{\circledR}$, has been consistently demonstrated $(50,52,53)$. In these studies, the $\mathrm{CuMV}_{\text {TT }}$ VLPs was screened in a comparative adjuvant study with alum. Table 4 summarizes the findings from a comparative adjuvant study using $\mathrm{CuMV}_{\mathrm{TT}}$ in the Malaria disease model, which highlights the effectiveness in combining nanoparticles with $\mathrm{MCT}^{\circledR}$ as an optimal way to formulate VLP-vaccines, taking advantage of the physiological properties of the lymphatic system.

In this study, the vaccine efficacy in the malaria survival challenge models were significantly improved if the vaccines were formulated with $\mathrm{MCT}^{\circledR}$, compared to alum. This was explained, in part, due to the high and sustained $\mathrm{Ab}$ titres induced in a step-wise improvement by adding $\mathrm{MCT}^{\circledR}$ (compared to non-adjuvanted groups) which indicated a more

TABLE 3 | Immunological mechanisms of VLP-based vaccines complement other adjuvants like MCT ${ }^{\circledR}$ and may provide added benefit (29, 43, 45, 47-66-68).

VLP scaffold

Repetitive and native antigen display - optimal BCR-crosslinking (PAMP; Pathogen Associated Molecular Pattern) Complement activation

Recognition by natural Abs and other innate humoral factors

Fast - transient migration to draining lymph nodes

Co-delivered adjuvant (e.g., TLR-ligands)
Local inflammation (early innate responses) Inflammasome activation

DC activation

Particulate for APC targeting

$B$ cell activation

T cell activation

Depot - prolong immune-exposure 
polarized Th1 biomarker specificity compared to alum as indicated by the IgG subset data (see Table 4).

\section{CuMV $_{\mathrm{TT}}-\mathrm{MCT}^{\circledR}$ in a Cancer (melanoma) Model}

Combining CuMVTT $\mathrm{TT}^{-}$VLPs displaying $\mathrm{T}$ cell epitopes with $\mathrm{MCT}^{\circledR}$ as an adjuvant has been tested in an aggressive transplanted melanoma murine model B16F10. The results showed improved anti-tumor efficacy when formulating the nano-vaccine with the micro-sized adjuvant MCT $^{\circledR}$ (Figure 4). This hybrid system facilitated an optimal delivery of the vaccine to efficiently prime the adaptive immune system. Furthermore, the $\mathrm{MCT}^{\circledR}$ adjuvant was as potent as $\mathrm{B}$ type $\mathrm{CpG}$ in a direct comparative assessment of efficacy. These findings highlight the translational potential for application for any solid tumor.

\section{CONCLUSIONS}

- $\mathrm{MCT}^{\circledR}$ is the crystalline formulation of the non-essential amino acid L-Tyrosine, biodegradable, with an estimated half-life of $48 \mathrm{~h}$ at the site of injection $(44,80)$.

- Formulated as a depot for controlled release from injection site - immunomodulation with allergens, antigens, whole cells, polysaccharides, and lipids.

- Characterized adsorption capacity and stability (broad vaccine scope) facilitating Th1-specific immunological augmentation.

- $\mathrm{MCT}^{\circledR}$ and Alum $[\mathrm{AlO}(\mathrm{OH})]$ are both distinct crystalline depot adjuvant formulations and induced broadly comparable B- and T-cell responses in mice (45).

- MCT $^{\circledR}$ induced less Th2 polarisation than Alum (less IL-4 and $\operatorname{IgE}$ ). A higher ratio of $\operatorname{IgG} / \operatorname{IgE}$ (i.e., relatively higher

TABLE 4 | Summary of vaccine efficacy with $\mathrm{MCT}^{\circledR}$ and Alum - depot adjuvants. The respective studies conjugated CuMV (independent of $\mathrm{CuMV}_{\mathrm{TT}}$ ). Formulations were compared against vaccines formulated with Alum.

\begin{tabular}{|c|c|c|c|c|}
\hline Formulations screened & Humoral response & Cellular response (CD8+ T cells) & Vaccine efficacy in survival challenge & Reference \\
\hline CMVtt-PvTRAP + MCT $^{\circledR}$ & $\begin{array}{l}{ }^{* \star}\left(\mathrm{PVTRAP}+\mathrm{MCT}^{\circledR}\right) \\
\lg \mathrm{g} 2 \mathrm{~b}>\lg \mathrm{lg} 2 \mathrm{a}>\lg \mathrm{G} 1\end{array}$ & ** (PVTRAP + MCT $\left.^{\circledR}\right)$ & ${ }^{\star * \star}\left(\mathrm{PVTRAP}+\mathrm{MCT}^{\circledR}\right)$ & $(52)$ \\
\hline CSP + MCT $^{\circledR}$ & $\begin{array}{l}{ }^{\star *}\left(\mathrm{CSP}+\mathrm{MCT}^{\circledR}\right) \\
\lg \mathrm{G} 2 \mathrm{a}>\lg \mathrm{G} 2 \mathrm{~b}>\lg \mathrm{G} 1\end{array}$ & N.D & ${ }^{\star}\left(\mathrm{CSP}+\mathrm{MCT}^{\circledR}\right)$ & (53) \\
\hline
\end{tabular}

${ }^{* * *} p=0.0001{ }^{* *} p=0.001 ;{ }^{*} p=0.01$ (one week after second boost); N.D; not determined.

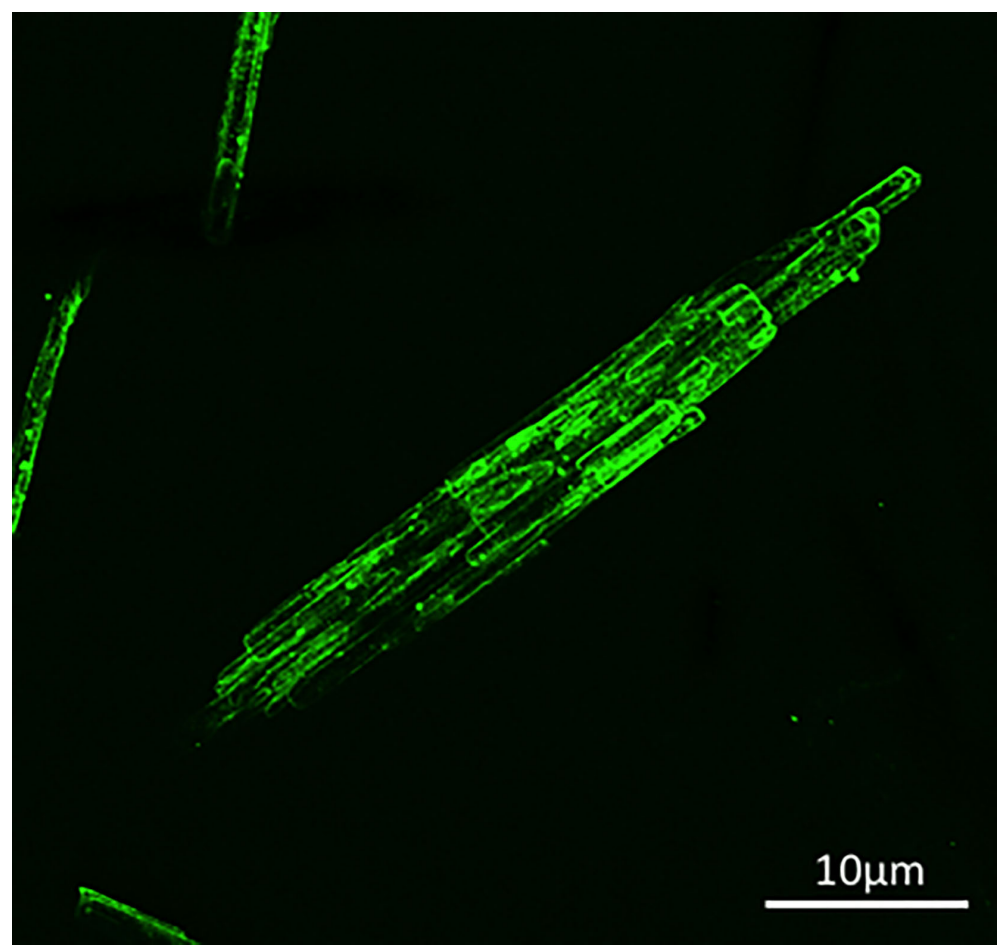

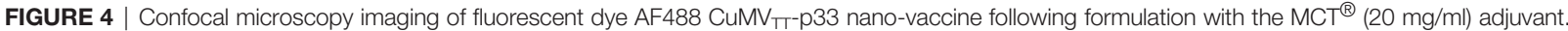


IgG to $\operatorname{IgE}$ ) which has been reported to be a surrogate marker indicative of efficacy of AIT in humans (81).

- MCT $^{\circledR}$ facilitates induction of CD8 T-cell responses $(45,50)$.

- $\quad$ AIT with $\mathrm{MCT}^{\circledR}$ adjuvanted allergens induce protection in a mouse model of anaphylaxis (45) and is formulated (adsorbed) with MPL ${ }^{\circledR}$ as an adjuvant system to provide short-course AIT in humans.

- MCT $^{\circledR}$ induces IL-1 $\beta$ secretion in vitro, but inflammasome activation does not affect B- and T-cell responses in vivo (45).

- MCT $^{\circledR}$ acts independent of TLR activation (45).

- The combination of $\mathrm{MCT}^{\circledR}$ with poorly immunogenic antigens such as Ovalbumin (45), CSP (53) and H1N1 (54) produce consistent results in generating a robust $\mathrm{B}$ cell response and protective efficacy in preclinical challenge models.

- The adsorption of MCT with $\mathrm{CuMV}_{\mathrm{TT}}$ virus-like-particles demonstrates significant added benefit in enhancing immunological ( $\mathrm{B}$ and $\mathrm{T}$ cells) responses in Malaria and Cancer (Melanoma) preclinical disease models $(50,52)$.

\section{REFERENCES}

1. Andreae H. [Edward Jenner, initiator of cowpox vaccination against human smallpox, died 150 years ago]. Das Offentl Gesundheitswes (1973) 35 (6):366-7.

2. Fenner F, Henderson DA, Arita I, Jezek Z, Ladnyi ID, World Health O. Smallpox and its eradication / F. Fenner. [et al.]. Geneva: World Health Organization (1988).

3. Riedel S. Edward Jenner and the history of smallpox and vaccination. Proc (Bayl Univ Med Cent) (2005) 18(1):21-5. doi: 10.1080/08998280.2005.11928028

4. Lamabadusuriya SP. Measles, mumps, rubella (MMR) vaccine. Ceylon Med J (2011) 56(3):135. doi: 10.4038/cmj.v56i3.3613

5. Bandyopadhyay AS, Garon J, Seib K, Orenstein WA. Polio vaccination: past, present and future. Future Microbiol (2015) 10(5):791-808. doi: 10.2217/ fmb.15.19

6. Luca S, Mihaescu T. History of BCG Vaccine. Maedica (2013) 8(1):53-8.

7. Mahairas GG, Sabo PJ, Hickey MJ, Singh DC, Stover CK. Molecular analysis of genetic differences between Mycobacterium bovis BCG and virulent M. bovis. J Bacteriol (1996) 178(5):1274. doi: 10.1128/JB.178.5. 1274-1282.1996

8. Calmette A. The Protection of Mankind against Tuberculosis: Being an Address before the Medico-Chirurgical Society of Edinburgh. Edinb Med J (1922) 29(1):93-104.

9. Sun W, Singh AK. Plague vaccine: recent progress and prospects. NPJ Vaccines (2019) 4(1):11. doi: 10.1038/s41541-019-0105-9

10. Girard G. [IMMUNITY IN PLAGUE. ACQUISITIONS SUPPLIED BY 30 YEARS OF WORK ON THE "PASTEURELLA PESTIS EV” (GIRARD AND ROBIC) STRAIN]. Biol Med (Paris) (1963) 52:631-731.

11. Campa R, Merton RK, Barber E. The Travels and Adventures of Serendipity: A Study in Sociological Semantics and the Sociology of Science. Int Sociol (2007) 22:1-14. doi: 10.1177/0268580907074544

12. Moloney PJ. THE PREPARATION AND TESTING OF DIPHTHERIA TOXOID (ANATOXINE-RAMON). Am J Public Health (N Y) (1926) 16 (12):1208-10. doi: 10.2105/AJPH.16.12.1208

13. Glenny AT, Hopkins BE. Diphtheria Toxoid as an Immunising Agent. $\mathrm{Br} J$ Exp Pathol (1923) 4(5):283-8.

14. Oakley CL. Alexander Thomas Glenny. 1882-1965. Biographical Memoirs Fellows R Soc (1966) 12:163-80. doi: 10.1098/rsbm.1966.0007

15. Ramon G. The toxin and anatoxin of diphtheria. Flocculating power and immunizing properties. Ann Inst Pasteur (Paris) (1924) 38:1-10.

16. Di Pasquale A, Preiss S, Tavares Da Silva F, Garçon N. Vaccine Adjuvants: from 1920 to 2015 and Beyond. Vaccines (2015) 3(2):320-43. doi: 10.3390/ vaccines 3020320

\section{AUTHOR CONTRIBUTIONS}

$\mathrm{MH}$ conceived and wrote the manuscript. MB, TK, MK, and MS are senior authors and chief or principal investigators of the MCT-based research and contributed to the scope and discussions. SH and MS are inventors of MCT technology and contributed to the scope and discussion. TC and MM designed the figures. P-JK contributed to the clinical development sections. All authors contributed to the article and approved the submitted version.

\section{FUNDING}

$\mathrm{MM}$ and $\mathrm{MB}$ is associated with the following funding agencies, which supported work reviewed in this manuscript; Qatar National Research Fund (PDRA4-0118-18002) and Swiss Cancer League (KFS-4291-08-2017).
17. Barr M, Glenny AT, Butler NR. Immunization of babies with diphtheriatetanus-pertusis prophylactic. $\mathrm{Br}$ Med J (1955) 2(4940):635-9. doi: 10.1136/bmj.2.4940.635

18. Wen Y, Shi Y. Alum: an old dog with new tricks. Emerg Microbes Infect (2016) 5(1):1-5. doi: 10.1038/emi.2016.40

19. Glenny AT, Buttle GAH, Stevens M. Rate of disappearance of diphtheria toxoid injected into rabbits and guinea - pigs: Toxoid precipitated with alum. J?Pathol Bacteriol (2005) 34:267-75. doi: 10.1002/path.1700340214

20. Shardlow E, Mold M, Exley C. Unraveling the enigma: elucidating the relationship between the physicochemical properties of aluminium-based adjuvants and their immunological mechanisms of action. Allergy Asthma Clin Immunol (2018) 14(1):80. doi: 10.1186/s13223-018-0305-2

21. Kool M, Pétrilli V, De Smedt T, Rolaz A, Hammad H, van Nimwegen M, et al. Cutting Edge: Alum Adjuvant Stimulates Inflammatory Dendritic Cells through Activation of the NALP3 Inflammasome. J?Immunol (2008) 181 (6):3755. doi: 10.4049/jimmunol.181.6.3755

22. Eisenbarth SC, Colegio OR, O'Connor W, Sutterwala FS, Flavell RA. Crucial role for the Nalp3 inflammasome in the immunostimulatory properties of aluminium adjuvants. Nature (2008) 453(7198):1122-6. doi: 10.1038/nature06939

23. Sun H, Pollock KGJ, Brewer JM. Analysis of the role of vaccine adjuvants in modulating dendritic cell activation and antigen presentation in vitro. Vaccine (2003) 21(9):849-55. doi: 10.1016/S0264-410X(02)00531-5

24. Hogenesch H. Mechanism of immunopotentiation and safety of aluminum adjuvants. Front Immunol (2013) 3:406-6. doi: 10.3389/fimmu.2012.00406

25. Hutchison S, Benson R, Gibson V, Pollock A, Garside P, Brewer J. Antigen depot is not required for alum adjuvanticity. FASEB J (2011) 26:1272-9. doi: 10.1096/fj.11-184556

26. McKee AS, Munks MW, MacLeod MKL, Fleenor CJ, Van Rooijen N, Kappler JW, et al. Alum induces innate immune responses through macrophage and mast cell sensors, but these sensors are not required for alum to act as an adjuvant for specific immunity. J Immunol (Baltimore Md. 1950) (2009) 183 (7):4403-14. doi: 10.4049/jimmunol.0900164

27. De Gregorio E, Rappuoli R. From empiricism to rational design: a personal perspective of the evolution of vaccine development. Nat Rev Immunol (2014) 14(7):505-14. doi: 10.1038/nri3694

28. O'Hagan DT, Fox CB. New generation adjuvants - From empiricism to rational design. Vaccine (2015) 33:B14-20. doi: 10.1016/j.vaccine.2015.01.088

29. Mohsen M, Augusto G, Bachmann M. The 3Ds in virus-like particle basedvaccines: “Design, Delivery and Dynamics". Immunol Rev (2020) 296:155-68. doi: 10.1111/imr.12863

30. Mohsen MO, Zha L, Cabral-Miranda G, Bachmann MF. Major findings and recent advances in virus-like particle (VLP)-based vaccines. Semin Immunol (2017) 34:123-32. doi: 10.1016/j.smim.2017.08.014 
31. Cornuz J, Zwahlen S, Jungi WF, Osterwalder J, Klingler K, van Melle G, et al. A Vaccine against Nicotine for Smoking Cessation: A Randomized Controlled Trial. PloS One (2008) 3(6):e2547. doi: 10.1371/journal.pone.0002547

32. Kündig TM, Senti G, Schnetzler G, Wolf C, Prinz Vavricka BM, Fulurija A, et al. Der $\mathrm{p} 1$ peptide on virus-like particles is safe and highly immunogenic in healthy adults. J Allergy Clin Immunol (2006) 117(6):1470-6. doi: 10.1016/ j.jaci.2006.01.040

33. Speiser DE, Schwarz K, Baumgaertner P, Manolova V, Devevre E, Sterry W, et al. Memory and Effector CD8 T-cell Responses After Nanoparticle Vaccination of Melanoma Patients. J Immunother (2010) 33(8):848-58. doi: 10.1097/CJI.0b013e3181f1d614

34. Spohn G, Schori C, Keller I, Sladko K, Sina C, Guler R, et al. Preclinical efficacy and safety of an anti-IL-1 $\beta$ vaccine for the treatment of type 2 diabetes. Mol Ther Methods Clin Dev (2014) 1:14048-8. doi: 10.1038/mtm.2014.48

35. Didierlaurent AM, Laupèze B, Di Pasquale A, Hergli N, Collignon C, Garçon N. Adjuvant system AS01: helping to overcome the challenges of modern vaccines. Expert Rev Vaccines (2017) 16(1):55-63. doi: 10.1080/ 14760584.2016.1213632

36. Akira S, Uematsu S, Takeuchi O. Pathogen Recognition and Innate Immunity. Cell (2006) 124(4):783-801. doi: 10.1016/j.cell.2006.02.015

37. Mogensen TH. Pathogen recognition and inflammatory signaling in innate immune defenses. Clin Microbiol Rev (2009) 22(2):240-73. doi: 10.1128/ CMR.00046-08

38. Maizels RM. Parasitic helminth infections and the control of human allergic and autoimmune disorders. Clin Microbiol Infect (2016) 22(6):481-6. doi: 10.1016/j.cmi.2016.04.024

39. Cruz AA, Cooper PJ, Figueiredo CA, Alcantara-Neves NM, Rodrigues LC, Barreto ML. Global issues in allergy and immunology: Parasitic infections and allergy. J Allergy Clin Immunol (2017) 140(5):1217-28. doi: 10.1016/ j.jaci.2017.09.005

40. Warner J. Obesity and allergic disease: Closely related epidemics of the 21st century: Editorial. Pediatr Allergy Immunol (2009) 20:305-6. doi: 10.1111/ j.1399-3038.2009.00888.x

41. Jutel M, Agache I, Bonini S, Burks AW, Calderon M, Canonica W, et al. International Consensus on Allergen Immunotherapy II: Mechanisms, standardization, and pharmacoeconomics. J Allergy Clin Immunol (2016) 137(2):358-68. doi: 10.1016/j.jaci.2015.12.1300

42. Bachmann MF, Mohsen MO, Kramer MF, Heath MD. Vaccination against Allergy: A Paradigm Shift? Trends Mol Med (2020) 26(4):357-68. doi: 10.1016/j.molmed.2020.01.007

43. Baldrick P, Richardson D, Wheeler AW. Review of L-tyrosine confirming its safe human use as an adjuvant. J Appl Toxicol (2002) 22(5):333-44. doi: 10.1002/jat.869

44. Wheeler AW, Moran DM, Robins BE, Driscoll A. 1-Tyrosine as an immunological adjuvant. Int Arch Allergy Appl Immunol (1982) 69(2):1139. doi: $10.1159 / 000233157$

45. Leuthard DS, Duda A, Freiberger SN, Weiss S, Dommann I, Fenini G, et al. Microcrystalline Tyrosine and Aluminum as Adjuvants in Allergen-Specific Immunotherapy Protect from IgE-Mediated Reactivity in Mouse Models and Act Independently of Inflammasome and TLR Signaling. J Immunol (2018) 200(9):3151-9. doi: 10.4049/jimmunol.1800035

46. Starchenka S, Heath MD, Lineberry A, Higenbottam T, Skinner MA. Transcriptome analysis and safety profile of the early-phase clinical response to an adjuvanted grass allergoid immunotherapy. World Allergy Organ J (2019) 12(11):100087. doi: 10.1016/j.waojou.2019.100087

47. Wheeler AW, Marshall JS, Ulrich JT. A Th1-inducing adjuvant, MPL, enhances antibody profiles in experimental animals suggesting it has the potential to improve the efficacy of allergy vaccines. Int Arch Allergy Immunol (2001) 126(2):135-9. doi: 10.1159/000049504

48. Rosewich M, Lee D, Zielen S. Pollinex Quattro: An innovative four injections immunotherapy In allergic rhinitis. Hum Vaccines Immunother (2013) 9 (7):1523-31. doi: 10.4161/hv.24631

49. Worm M, Higenbottam T, Pfaar O, Mösges R, Aberer W, Gunawardena K, et al. Randomized controlled trials define shape of dose response for Pollinex Quattro Birch allergoid immunotherapy. Allergy (2018) 73(9):1812-22. doi: 10.1111/all.13478

50. Mohsen MO, Heath MD, Cabral-Miranda G, Lipp C, Zeltins A, Sande M, et al. Vaccination with nanoparticles combined with micro-adjuvants protects against cancer. J Immunother Cancer (2019) 7(1):114. doi: 10.1186/s40425-019-0616-y
51. Zeltins A, West J, Zabel F, El Turabi A, Balke I, Haas S, et al. Incorporation of tetanus-epitope into virus-like particles achieves vaccine responses even in older recipients in models of psoriasis, Alzheimer's and cat allergy. NPJ Vaccines (2017) 2(1):30. doi: 10.1038/s41541-017-0030-8

52. Cabral-Miranda G, Heath MD, Mohsen MO, Gomes AC, Engeroff P, Flaxman A, et al. Virus-Like Particle (VLP) Plus Microcrystalline Tyrosine (MCT) Adjuvants Enhance Vaccine Efficacy Improving T and B Cell Immunogenicity and Protection against Plasmodium berghei/vivax. Vaccines (2017) 5(2):10. doi: $10.3390 /$ vaccines 5020010

53. Cabral-Miranda G, Heath MD, Gomes AC, Mohsen MO, Montoya-Diaz E, Salman AM, et al. Microcrystalline Tyrosine $\left(\mathrm{MCT}\left({ }^{\circledR}\right)\right)$ : A Depot Adjuvant in Licensed Allergy Immunotherapy Offers New Opportunities in Malaria. Vaccines (2017) 5(4):32. doi: 10.3390/vaccines5040032

54. Heath MD, Swan NJ, Marriott AC, Silman NJ, Hallis B, Prevosto C, et al. Comparison of a novel microcrystalline tyrosine adjuvant with aluminium hydroxide for enhancing vaccination against seasonal influenza. BMC Infect Dis (2017) 17(1):232. doi: 10.1186/s12879-017-2329-5

55. Zielen S, Kuna P, Aberer W, Lassmann S, Pfaar O, Klimek L, et al. Strong dose response after immunotherapy with $\mathrm{PQ}$ grass using conjunctival provocation testing. World Allergy Organ J (2019) 12(11):100075-5. doi: 10.1016/ j.waojou.2019.100075

56. Roberts G, Pfaar O, Akdis CA, Ansotegui IJ, Durham SR, Gerth van Wijk R, et al. EAACI Guidelines on Allergen Immunotherapy: Allergic rhinoconjunctivitis. Allergy (2018) 73(4):765-98. doi: 10.1111/all.13317

57. Jensen-Jarolim E. Aluminium in Allergies and Allergen immunotherapy. World Allergy Organ J (2015) 8:7. doi: 10.1186/s40413-015-0060-5

58. Patel P, Holdich T, Fischer von Weikersthal-Drachenberg KJ, Huber B. Efficacy of a short course of specific immunotherapy in patients with allergic rhinoconjunctivitis to ragweed pollen. J Allergy Clin Immunol (2014) 133 (1):121-9.e1-2. doi: 10.1016/j.jaci.2013.05.032

59. Puggioni F, Durham SR, Francis JN. Monophosphoryl lipid A (MPL) promotes allergen-induced immune deviation in favour of Th1 responses. Allergy (2005) 60(5):678-84. doi: 10.1111/j.1398-9995.2005.00762.x

60. Laupèze B, Hervé C, Di Pasquale A, Tavares Da Silva F. Adjuvant Systems for vaccines: 13 years of post-licensure experience in diverse populations have progressed the way adjuvanted vaccine safety is investigated and understood. Vaccine (2019) 37(38):5670-80.

61. Jensen-Jarolim E, Bachmann MF, Bonini S, Jacobsen L, Jutel M, Klimek L, et al. State-of-the-art in marketed adjuvants and formulations in Allergen Immunotherapy: A position paper of the European Academy of Allergy and Clinical Immunology (EAACI). Allergy (2020) 75(4):746-60. doi: 10.1111/ all.14134

62. Oleszycka E, Moran H. B, Tynan GA, Hearnden CH, Coutts G, Campbell M, et al. IL- $1 \alpha$ and inflammasome-independent IL- $1 \beta$ promote neutrophil infiltration following alum vaccination. FEBS $J$ (2016) 283(1):9-24. doi: 10.1111/febs. 13546

63. Bell AJ, Heath MD, Hewings SJ, Skinner MA. The adsorption of allergoids and 3-O-desacyl-4'-monophosphoryl lipid A (MPL $\left.{ }^{\circledR}\right)$ to microcrystalline tyrosine (MCT) in formulations for use in allergy immunotherapy. J Inorg Biochem (2015) 152:147-53. doi: 10.1016/j.jinorgbio.2015.08.007

64. Shardlow E, Exley C. The size of micro-crystalline tyrosine $\left(\mathrm{MCT}^{\circledR}\right)$ influences its recognition and uptake by THP-1 macrophages in vitro. RSC Adv (2019) 9 (42):24505-18. doi: 10.1039/C9RA03831K

65. Pratten MK, Lloyd JB. Pinocytosis and phagocytosis: the effect of size of a particulate substrate on its mode of capture by rat peritoneal macrophages cultured in vitro. Biochim Biophys Acta (BBA) - Gen Subj (1986) 881(3):30713. doi: $10.1016 / 0304-4165(86) 90020-6$

66. Bachmann M, Jennings G. Vaccine delivery: A matter of size, geometry, kinetics and molecular patterns. Nat Rev Immunol (2010) 10:787-96. doi: $10.1038 /$ nri2868

67. Mohsen MO, Gomes AC, Vogel M, Bachmann MF. Interaction of Viral Capsid-Derived Virus-Like Particles (VLPs) with the Innate Immune System. Vaccines (2018) 6(3):37. doi: 10.3390/vaccines6030037

68. Vogel M, Bachmann MF. Immunogenicity and Immunodominance in Antibody Responses. Curr Top Microbiol Immunol (2019). doi: 10.1007/82_2019_160

69. Link A, Zabel F, Schnetzler Y, Titz A, Brombacher F, Bachmann MF. Innate immunity mediates follicular transport of particulate but not soluble protein antigen. J Immunol (2012) 188(8):3724-33. doi: 10.4049/jimmunol.1103312 
70. Goldinger SM, Dummer R, Baumgaertner P, Mihic-Probst D, Schwarz K, Hammann-Haenni A, et al. Nano-particle vaccination combined with TLR-7 and -9 ligands triggers memory and effector $\mathrm{CD}^{+}$T-cell responses in melanoma patients. Eur J Immunol (2012) 42(11):3049-61. doi: 10.1002/ eji.201142361

71. Anzaghe M, Schülke S, Scheurer S. Virus-Like Particles as Carrier Systems to Enhance Immunomodulation in Allergen Immunotherapy. Curr Allergy Asthma Rep (2018) 18(12):71. doi: 10.1007/s11882-018-0827-1

72. Cabral-Miranda G, Lim SM, Mohsen MO, Pobelov IV, Roesti ES, Heath MD, et al. Zika Virus-Derived E-DIII Protein Displayed on Immunologically Optimized VLPs Induces Neutralizing Antibodies without Causing Enhancement of Dengue Virus Infection. Vaccines (2019) 7(3):72. doi: $10.3390 /$ vaccines7030072

73. von Loga IS, El-Turabi A, Jostins L, Miotla-Zarebska J, Mackay-Alderson J, Zeltins A, et al. Active immunisation targeting nerve growth factor attenuates chronic pain behaviour in murine osteoarthritis. Ann Rheum Dis (2019) 78 (5):672-5. doi: 10.1136/annrheumdis-2018-214489

74. Storni F, Zeltins A, Balke I, Heath MD, Kramer MF, Skinner MA, et al. Vaccine against peanut allergy based on engineered virus-like particles displaying single major peanut allergens. J Allergy Clin Immunol (2020) 145 (4):1240-53.e3. doi: 10.1016/j.jaci.2019.12.007

75. Thoms F, Jennings G. T, Maudrich M, Vogel M, Haas S, Zeltins A, et al. Immunization of cats to induce neutralizing antibodies against Fel $\mathrm{d} 1$, the major feline allergen in human subjects. J Allergy Clin Immunol (2019) 144 (1):193-203. doi: 10.1016/j.jaci.2019.01.050

76. Bachmann MF, Zeltins A, Kalnins G, Balke I, Fischer N, Rostaher A, et al. Vaccination against IL-31 for the treatment of atopic dermatitis in dogs. J Allergy Clin Immunol (2018) 142(1):279-81.e1. doi: 10.1016/j.jaci. 2017.12.994

77. Fettelschoss-Gabriel A, Fettelschoss V, Olomski F, Birkmann K, Thoms F, Bühler $\mathrm{M}$, et al. Active vaccination against interleukin-5 as long-term treatment for insect-bite hypersensitivity in horses. Allergy (2019) 74 (3):572-82. doi: 10.1111/all.13659
78. Olomski F, Fettelschoss V, Jonsdottir S, Birkmann K, Thoms F, Marti E, et al Interleukin 31 in insect bite hypersensitivity-Alleviating clinical symptoms by active vaccination against itch. Allergy (2020) 75(4):862-71. doi: 10.1111/all.14145

79. Engeroff P, Caviezel F, Storni F, Thoms F, Vogel M, Bachmann MF. Allergens displayed on virus-like particles are highly immunogenic but fail to activate human mast cells. Allergy (2018) 73(2):341-9. doi: 10.1111/all.13268

80. McDougall S, Heath M, Kramer M, Skinner M. Analysis of aluminium in rat following administration of allergen immunotherapy using either aluminium or microcrystalline-tyrosine-based adjuvants. Bioanalysis (2016) 8:547-56. doi: 10.4155/bio.16.10

81. Shamji MH, Kappen J. H, Akdis M, Jensen-Jarolim E, Knol EF, Kleine-Tebbe J, et al. Biomarkers for monitoring clinical efficacy of allergen immunotherapy for allergic rhinoconjunctivitis and allergic asthma: an EAACI Position Paper. Allergy (2017) 72(8):1156-73. doi: 10.1111/all.13138

Conflict of Interest: MH, P-JK, MK, TC, SH, and MS are all employees of Allergy Therapeutics Plc (ATLp) who develop and manufacture immunotherapies and diagnostics, including the MCT adjuvant. MM, MB, and TK are under consultancy agreements with ATLp. ML was employed by Bencard Allergie GmbH. MB and TK are co-founders of Saiba $\mathrm{GmbH}$ who have out licensed vaccine development of $\mathrm{CuMV}_{\mathrm{TT}}$ to ATLp within allergy and other disease indications.

The remaining authors declare that the research was conducted in the absence of any commercial or financial relationships that could be construed as a potential conflict of interest.

Copyright (c) 2020 Heath, Mohsen, de Kam, Carreno Velazquez, Hewings, Kramer, Kündig, Bachmann and Skinner. This is an open-access article distributed under the terms of the Creative Commons Attribution License (CC BY). The use, distribution or reproduction in other forums is permitted, provided the original author(s) and the copyright owner(s) are credited and that the original publication in this journal is cited, in accordance with accepted academic practice. No use, distribution or reproduction is permitted which does not comply with these terms. 